\title{
EFEKTIVITAS VARIASI KONSENTRASI LARUTAN AIR GARAM DAN VARIASI WAKTU PERENDAMAN DALAM MENURUNKAN KADAR FORMALIN PADA TAHU PUTIH
}

\author{
Suprapti ${ }^{1)}$, Budi Utomo' ${ }^{2)}$, Asep Tata Gunawan ${ }^{3)}$ \\ Jurusan Kesehatan Lingkungan Politeknik Kesehatan Kemenkes Semarang \\ Jl. Raya Baturaden KM 12 Purwokerto, Indonesia
}

\begin{abstract}
Abstrak
Kandungan protein dan kadar air tahu yang cukup tinggi menyebabkan tahu tidak dapat bertahan lama, sehingga ada pedagang yang menggunakan formalin sebagai pengawet. Formalin merupakan bahan beracun dan berbahaya bagi kesehatan manusia. Tujuan penelitian ini adalah untuk mengetahui variasi kadar garam dan variasi waktu yang efektif untuk menurunkan kadar formalin pada tahu. Desain penelitian ini adalah True Experimental dengan dengan bentuk posttest only control group design. Sampel diambil dengan metode Simple Random Sampling. Uji hipotesis secara statistik dengan menggunakan uji Anova Factorial dengan $\alpha=0,005$. Konsentrasi larutan air garam 5\%, dapat menurunkan kadar formalin rata-rata 2.702 ppm (16\%); konsentrasi 10\% menurunkan 5.741 ppm (34\%); dan konsentrasi 15\%, dapat menurunkan 8.655 ppm (51\%). Perendaman selama 15 menit dapat menurunkan formalin rata-rata 5.714 ppm (33\%); perendaman 30 menit menurunkan 5.261 ppm (31\%); dan perendaman 60 menit menurunkan 6.122 ppm 36). Interaksi konsentrasi 15\% selama 60 menit menurunkan kadar formalin tahu optimal rata-rata sebesar 9.575 ppm (62\%). Semua variasi konsentrasi larutan air garam dan variasi waktu perendaman dapat menurunkan kadar formalin pada tahu putih.
\end{abstract}

Kata kunci $\quad$ : formalin, konsentrasi garam, waktu perendaman

\begin{abstract}
The protein content and the water level in tofu are high enough. It can not be long lasting, so there are merchants that use formaldehyde as a preservative. Formalin is toxic and harmful to human health. This study aimed to determine the effectiveness of various concentration of brine solution and soaking time variation in lowering levels of formalin tofu. This study design is True Experimental with the shape Posttest only control group design. Samples were taken by simple random sampling method. Analysis of data is done statistically by using factorial ANOVA test with $\alpha=0.005$. The concentration of $5 \%$ salt water solution, can reduce levels of formaldehyde on average 2,702 ppm (16\%); concentration of $10 \%$ can reduce 5,741 ppm (34\%); and the concentration of $15 \%$, can reduce 8655 ppm (51\%). Soaking for 15 minutes can reduce formaldehyde average of 5,714 ppm (33\%); soaking 30 minutes lowers 5261 ppm (31\%); and soaking 60 minutes lowers 6122 ppm (36). Interaction between concentration of 15\% dan soaking 60 minutes lowers $9.575 \mathrm{ppm}(62 \%)$. All variations in the concentration of brine solution and soaking time variations can reduce levels of formaldehyde in a white tofu.
\end{abstract}

Keyword $\quad:$ formalin, immersion time, salt concentration

\section{PENDAhuluan}

Makanan merupakan kebutuhan pokok bagi setiap manusia karena di dalamnya terkandung senyawa-senyawa yang sangat diperlukan untuk memulihkan dan memperbaiki jaringan tubuh yang rusak, mengatur proses dalam tubuh, dan menghasilkan energi untuk berbagai kegiatan dalam kehidupan.. Secara ilmiah makanan atau pangan didefinisikan sebagai sekumpulan bahan yang yang diperlukan untuk mempertahankan kehidupan dan fungsi normal dari makhluk hidup baik jasad renik, tumbuh-tumbuhan, hewan maupun manusia. Kebutuhan akan makanan diperoleh dari bebagai sumber nabati maupun hewani, yang produksinya umumnya bersifat musiman (Effendi, 2012, h. 1).

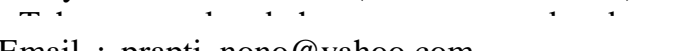

3) Email : aseptatagunawan@yahoo.co.id sehingga tahu tidak dapat bertahan lama. Pada suhu biasa (suhu kamar) daya tahannya rata-rata 1-2 hari. Kerusakan tahu ditandai dengan bau asam dan berlendir. Lebih dari batas tersebut, rasa tahu menjadi asam, busuk dan tidak layak konsumsi, sehingga pedagang menggunakan pengawet agar menjadi tahan lama. Salah satu pengawet yang sering digunakan adalah formalin (Saptarini, et al., 2011, h. 38).

Formalin merupakan bahan tambahan pangan yang dilarang oleh pemerintah. Larangan penggunaan formalin sudah diatur dalam PERMENKES RI No.033 tahun 2012 tentang Bahan Tambahan Makanan. Formalin merupakan larutan jernih, tidak berwarna, berbau tajam, mengandung formaldehide (HCO) sekitar $37 \%$ dalam air (Purawisastra dan Sahara, 2011, h. 64). Formalin 
(CH20) adalah campuran formaldehide dengan air. Formalin yang banyak ditemukan di pasaran umumnya mengandung konsentrasi formaldehida 37\%-40 \% (Singgih, 2013. h. 57).

Orang yang mengkonsumsi bahan pangan yang berformalin seperti tahu, mie, bakso, ayam, ikan dan bahkan permen, dalam beberapa kali belum merasakan akibatnya. Tapi efek dari bahan pangan berformalin baru dapat terasa beberapa tahun kemudian . Formalin dapat bereaksi cepat dengan lapisan lendir saluran pencernaan dan saluran pernafasan.

Formalin di dalam tubuh cepat teroksidasi membentuk asam format terutama di hati dan sel darah merah. Pemakaian pada makanan dapat mengakibatkan keracunan pada tubuh manusia, yaitu rasa sakit perut yang akut disertai muntah-muntah, timbulnya depresi susunan syaraf atau kegagalan peredaran darah (Hastuti, 2010, h. 132).

\section{BAHAN DAN METODE}

Variabel bebas penelitian ini adalah variasi konsentrasi larutan air garam dan variasi waktu perendaman . Yaitu konsentrasi larutan air garam perendaman : $5 \%, 10 \%$ dan $15 \%$ dan lama perendaman: 15 menit, 30 menit dan 60 menit. Variabel terikat penelitian ini adalah penurunan kadar formalin pada tahu setelah adanya proses perendaman larutan air garam dengan variasi konsentrasi larutan air garam dan variasi waktu perendaman. Variabel kontrol dalam penelitian ini adalah kualitas air perendaman (sumber dan $\mathrm{pH}$ ), sumber tahu dan wadah untuk perlakuan.

Jenis penelitian yang digunakan adalah true eksperimen dengan desain posttest only control group design. Dalam rancangan ini dilakukan randomisasi, yaitu pengelompokan anggota kelompok control dan kelompok eksperimen dilakukan secara acak atau random. Kelompokkelompok tersebut dianggap sama sebelum perlakuan. (Notoatmodjo, 2010, h. 60). Dengan rancangan ini memungkinkan peneliti mengukur pengaruh perlakuan (intervensi) pada kelompok eksperimen dengan cara membandingkan kelompok tersebut dengan kelompok kontrol.

Populasi penelitian ini adalah semua tahu putih di pedagang $x$ pasar Cilongok. Sampel pada penelitian ini adalah tahu yang diambil dengan metode Simple Random Sampling (Santjaka, 2011, h. 55). Kelompok sampel dibagi menjadi 2 yaitu kelompok kontrol (A0) dan kelompok perlakuan. Jumlah perlakuan pada penelitian ini ada 9 (sembilan). Desain perlakuan pada penelitian ini adalah :

Replikasi pada penelitian ini adalah 3 (tiga) kali, yang diperoleh dari rumus :

$$
=(\mathrm{T}-1)(\mathrm{R}-1)>15 \text {. }
$$

Keterangan : $\mathrm{T}=$ Perlakuan (9)

$$
\begin{aligned}
& \mathrm{R}=\text { Jumlah Replikasi tiap sampel } \\
& (9-1)(\mathrm{R}-1)>15
\end{aligned}
$$

$$
8 \mathrm{R}-8>15
$$

$$
8 \mathrm{R}>23
$$

$\square \mathrm{R}>2,875$ (3)

Analisis data yang dipakai untuk menganalisis secara bersama-sama efek dari perlakuan adalah analisis faktorial (anov factorial) atau jika perlakuan (variable independen) yang diberikan kepada subyek yang diteliti lebih dari satu dan perubahan pada subyek (variabel dependen) satu, maka digunakan analisis faktorial (Santjaka, 2011, h. 11).

Tabel 1 Desain Perlakuan Penelitian

\begin{tabular}{lcccc}
$\begin{array}{c}\text { Konsentrasi Larutan } \\
\text { Air Garam } \\
\text { Perendaman }\end{array}$ & $5 \%$ (A) & $10 \%(\mathrm{~B})$ & $\mathbf{1 5 \% ( C )}$ \\
\hline $\begin{array}{l}15 \text { Menit (1) } \\
30 \text { Menit (2) }\end{array}$ & $\mathrm{A} 1$ & $\mathrm{~B} 1$ & $\mathrm{C} 1$ \\
60 Menit (2) & $\mathrm{A} 2$ & $\mathrm{~B} 2$ & $\mathrm{C} 2$ \\
& $\mathrm{~B} 3$ & $\mathrm{C} 3$
\end{tabular}

\section{HASIL}

Tabel 2 Hasil Uji pH pada Air Perendaman Sampel

\begin{tabular}{clcclc}
\hline No & Perlakuan & pH & No & \multicolumn{1}{c}{ Perlakuan } & pH \\
\hline 1. & Air, 15 menit R1 & 7 & 19. & $5 \%, 15$ menit R2 & 7 \\
2. & Air, 30 menit R1 & 7 & 20 & $5 \%, 30$ menit R2 & 7 \\
3. & Air, 60 menit R1 & 7 & 21. & $5 \%, 60$ menit R2 & 7 \\
4. & Air, 15 menit R2 & 7 & 22. & $10 \%, 15$ menit R2 & 7 \\
5. & Air, 30 menit R2 & 7 & 23. & $10 \%, 30$ menit R2 & 7 \\
6. & Air, 60 menit R2 & 7 & 24. & $10 \%, 60$ menit R2 & 7 \\
7. & Air, 15 menit R3 & 7 & 25. & $15 \%, 15$ menit R2 & 7 \\
8. & Air, 30 menit R3 & 7 & 26. & $15 \%, 30$ menit R2 & 7 \\
9. & Air, 60 menit R3 & 7 & 27. & $15 \%, 60$ menit R2 & 7 \\
10. & $5 \%, 15$ menit R1 & 7 & 28. & $5 \%, 15$ menit R3 & 7 \\
11. & $5 \%, 30$ menit R1 & 7 & 29. & $5 \%, 30$ menit R3 & 7 \\
12. & $5 \%, 60$ menit R1 & 7 & 30. & $5 \%, 60$ menit R3 & 7 \\
13. & $10 \%, 15$ menit R1 & 7 & 31. & $10 \%, 15$ menit R3 & 7 \\
14. & $10 \%, 30$ menit R1 & 7 & 32. & $10 \%, 30$ menit R3 & 7 \\
15. & $10 \%, 60$ menit R1 & 7 & 33 & $10 \%, 60$ menit R3 & 7 \\
16. & $15 \%, 15$ menit R1 & 7 & 34. & $15 \%, 15$ menit R3 & 7 \\
17. & $15 \%, 30$ menit R1 & 7 & 35. & $15 \%, 30$ menit R3 & 7 \\
18. & $15 \%, 60$ menit R1 & 7 & 36. & $15 \%, 60$ menit R3 & 7 \\
\hline
\end{tabular}

Tabel 3 Hasil Uji Kuantitatif terhadap Sampel Tahu Putih pada Perendaman Air dengan Variasi Waktu

\begin{tabular}{llrc}
\hline No & Waktu Perendaman & $\begin{array}{c}\text { Kadar Formalin } \\
\text { (ppm) }\end{array}$ & $\begin{array}{c}\text { Kadar Formalin } \\
\text { Rata-rata (ppm) }\end{array}$ \\
\hline l. & 15 MENIT & 18.768 & \\
& & 18.735 & 18.752 \\
2. & \multirow{2}{*}{ 30 MENIT } & 18.752 & \\
& & 17.165 & \\
3. & & 16.996 & 17.070 \\
& & 17.074 & \\
& & 15.490 & \multirow{2}{*}{ MENIT } \\
\hline
\end{tabular}

Tabel 4 Hasil Uji Kuantitatif terhadap Sampel Tahu Putih dengan Variasi Kadar Larutan Air Garam dan Variasi Waktu Perendaman 


\begin{tabular}{lcrrr}
\hline NO & WAKTU & \multicolumn{3}{c}{ KADAR LARUTAN AIR GARAM } \\
\cline { 3 - 5 } 1. & PERENDAMAN & $\mathbf{5 \%}$ & $\mathbf{1 0} \%$ & $\mathbf{1 5 \%}$ \\
& 15 MENIT & 15.585 & 13.168 & 10.468 \\
& & 15.498 & 12.992 & 10.452 \\
& & 15.593 & 13.078 & 10.502 \\
& Jumlah & 46.676 & 39.238 & 31.422 \\
& Rata-rata & 15.559 & 13.079 & 10.474 \\
2. & 30 MENIT & 14.788 & 11.796 & 8.996 \\
& & 14.745 & 11.687 & 8.974 \\
& & 14.680 & 11.708 & 8.903 \\
& Jumlah & 51.209 & 35.191 & 26.873 \\
& Rata-rata & 17.070 & 11.730 & 8.958 \\
3. & 60 MENIT & 12.892 & 9.266 & 5.877 \\
& & 12.835 & 9.182 & 5.865 \\
& & 12.809 & 9.204 & 5.816 \\
& Jumlah & 38.536 & 27.652 & 17.558 \\
& Rata-rata & 12.845 & 9.217 & 5.853 \\
\hline
\end{tabular}

Tabel 5 Penurunan Kadar Formalin Sampel Tahu Putih (ppm) pada Perlakuan Variasi Konsentrasi Larutan Air Garam dan Variasi Waktu Perendaman

\begin{tabular}{|c|c|c|c|c|c|c|}
\hline \multirow[t]{2}{*}{ No } & \multirow{2}{*}{ Perlakuan } & \multirow[t]{2}{*}{ Replikasi } & \multicolumn{2}{|c|}{ Kadar Formalin } & \multicolumn{2}{|c|}{$\begin{array}{c}\text { Penurunan Kadar } \\
\text { Formalin }\end{array}$} \\
\hline & & & Kontrol & Perlakuan & ppm & $\%$ \\
\hline \multirow[t]{5}{*}{1} & $5 \%, 15$ menit & R1 & 18.768 & 15.585 & 3.183 & 17 \\
\hline & & R 2 & 18.735 & 15.498 & 3.237 & 17 \\
\hline & & & 18.752 & 15.593 & 3.159 & 17 \\
\hline & Jun & & 56.255 & 46.676 & 9.579 & 51 \\
\hline & Rata & & 18.752 & 15.559 & 3.193 & 17 \\
\hline \multirow[t]{5}{*}{2} & $5 \%, 30$ menit & R1 & 17.165 & 14.788 & 2.377 & 14 \\
\hline & & R 2 & 16.996 & 14.745 & 2.251 & 13 \\
\hline & & R3 & 17.048 & 14.680 & 2.368 & 14 \\
\hline & Jun & & 51.209 & 44.213 & 6.996 & 41 \\
\hline & Rata & & 17.170 & 14.738 & 2.332 & 14 \\
\hline \multirow[t]{5}{*}{3} & $5 \%, 60$ menit & R1 & 15.490 & 12.892 & 2.598 & 17 \\
\hline & & $\mathrm{R} 2$ & 15.406 & 12.835 & 2.571 & 17 \\
\hline & & R3 & 15.386 & 12.809 & 2.577 & 17 \\
\hline & Jun & & 46.282 & 38.536 & 7.746 & 51 \\
\hline & Rata & & 15.427 & 12.845 & 2.582 & 17 \\
\hline \multirow[t]{5}{*}{4} & $10 \%, 15$ menit & R1 & 18.768 & 13.168 & 5.600 & 30 \\
\hline & & R 2 & 18.735 & 12.992 & 5.743 & 31 \\
\hline & & R3 & 18.752 & 13.078 & 5.674 & 30 \\
\hline & Jun & & 56.255 & 39.238 & 17.017 & 91 \\
\hline & Rata & & 18.752 & 13.079 & 5.672 & 30 \\
\hline \multirow[t]{5}{*}{5} & $10 \%, 30$ menit & R1 & 17.165 & 11.796 & 5.369 & 31 \\
\hline & & R 2 & 16.996 & 11.687 & 5.309 & 31 \\
\hline & & R3 & 17.048 & 11.708 & 5.340 & 31 \\
\hline & & & 51.209 & 35.191 & 16.018 & 93 \\
\hline & Rata & & 17.070 & 11.730 & 5.339 & 31 \\
\hline \multirow[t]{5}{*}{6} & $10 \%, 60$ menit & R1 & 15.490 & 9.266 & 6.224 & 40 \\
\hline & & R 2 & 15.406 & 9.182 & 6.224 & 40 \\
\hline & & R3 & 15.386 & 9.204 & 6.182 & 40 \\
\hline & Jun & & & 27.652 & 18.630 & 120 \\
\hline & Rata & & 15.427 & 9.217 & 6.210 & 40 \\
\hline \multirow[t]{5}{*}{7} & $15 \%, 15$ menit & R1 & 18.768 & 10.468 & 8.300 & 44 \\
\hline & & R 2 & 18.735 & 10.452 & 8.283 & 44 \\
\hline & & R3 & 18.752 & 10.502 & 8.250 & 44 \\
\hline & Jun & & 56.255 & 31.422 & 24.833 & 132 \\
\hline & Rata & & 18.752 & 10.474 & 8.278 & 44 \\
\hline \multirow[t]{5}{*}{8} & $15 \%, 30$ menit & R1 & 17.165 & 8.996 & 8.169 & 48 \\
\hline & & R 2 & 16.996 & 8.974 & 8.022 & 47 \\
\hline & & R3 & 17.048 & 8.903 & 8.145 & 48 \\
\hline & Jun & & 51.209 & 26.873 & 24.336 & 143 \\
\hline & Rata & & 17.170 & 8.958 & 8.112 & 48 \\
\hline \multirow[t]{5}{*}{9} & $15 \%, 60$ menit & R1 & 15.490 & & 9.613 & 62 \\
\hline & & R 2 & 15.406 & 5.865 & 9.541 & 62 \\
\hline & & R3 & 15.386 & 5.816 & 9.570 & 62 \\
\hline & Jun & & 46.282 & 17.558 & 28.724 & 186 \\
\hline & Rata & & 15.427 & 5.858 & 9.575 & 62 \\
\hline
\end{tabular}

Tabel 6 Pengaruh Konsentrasi Larutan Air Garam 5\% dan Variasi Waktu Perendaman 15 Menit, 30 Menit, dan 60 Menit terhadap Penurunan Kadar Formalin Tahu Putih (ppm)

\begin{tabular}{|c|c|c|c|c|c|}
\hline \multirow[b]{2}{*}{ No } & \multirow{2}{*}{$\begin{array}{c}\text { Kosentrasi } \\
\text { Larutan Air } \\
\text { Garam }\end{array}$} & \multirow{2}{*}{$\begin{array}{c}\text { Waktu } \\
\text { Perendaman }\end{array}$} & \multirow{2}{*}{$\begin{array}{c}\text { Kadar } \\
\text { formalin } \\
\text { rata-rata } \\
\text { awal }\end{array}$} & \multicolumn{2}{|c|}{$\begin{array}{c}\text { Rata-rata Penurunan } \\
\text { Kadar Formalin }\end{array}$} \\
\hline & & & & ppm & $\%$ \\
\hline \multirow[t]{3}{*}{1} & $5 \%$ & 15 Menit & $\begin{array}{l}18.752 \\
17072\end{array}$ & 3.193 & 17 \\
\hline & & 60 Menit & $\begin{array}{l}17.072 \\
15.427\end{array}$ & $\begin{array}{l}2.351 \\
2.582\end{array}$ & 17 \\
\hline & & Total & 17.083 & 2.702 & 16 \\
\hline
\end{tabular}

Tabel 7 Pengaruh Konsentrasi Larutan Air Garam 10\% dan Variasi Waktu Perendaman 15 Menit, 30 Menit, dan 60 Menit terhadap Penurunan Kadar Formalin Tahu Putih (ppm)

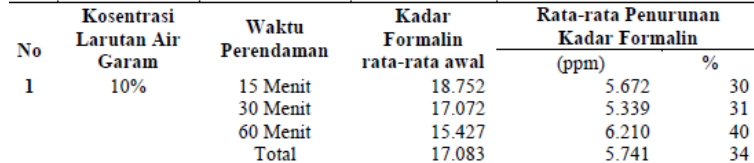

Tabel 8 Pengaruh Konsentrasi Larutan Air Garam 15\% dan Variasi Waktu Perendaman 15 Menit, 30 Menit, dan 60 Menit terhadap Penurunan Kadar Formalin Tahu Putih (ppm)

\begin{tabular}{|c|c|c|c|c|c|}
\hline \multirow[t]{2}{*}{ No } & \multirow{2}{*}{$\begin{array}{c}\text { Kosentrasi } \\
\text { Larutan Air } \\
\text { Garam }\end{array}$} & \multirow{2}{*}{$\begin{array}{c}\text { Waktu } \\
\text { Perendaman }\end{array}$} & \multirow{2}{*}{$\begin{array}{c}\text { Kadar } \\
\text { Formalin } \\
\text { rata-rata awal }\end{array}$} & \multicolumn{2}{|c|}{$\begin{array}{l}\text { Rata-rata Penurunan Kadar } \\
\text { Formalin }\end{array}$} \\
\hline & & & & $\mathrm{ppm}$ & $\%$ \\
\hline 1 & $15 \%$ & & 18.752 & 8.278 & \\
\hline & & & 17.0 & 8.1 & \\
\hline & & & & 9.575 & \\
\hline & & Total & 17.083 & 8.655 & \\
\hline
\end{tabular}

Tabel 9 Pengaruh Variasi Konsentrasi Larutan Air Garam terhadap Penurunan Kadar Formalin Tahu Putih (ppm)

\begin{tabular}{cccc}
\hline \multirow{2}{*}{ No } & Kadar Garam & \multicolumn{2}{c}{ Rata-rata Penurunan Kadar Formalin } \\
\cline { 2 - 4 } 1. & $5 \%$ & Ppm & $\%$ \\
2. & $10 \%$ & 2.702 & 16 \\
3. & $15 \%$ & 5.741 & 34 \\
\hline
\end{tabular}

Tabel 10 Pengaruh Variasi Wakut Perendaman terhadap Penurunan Kadar Formalin Tahu Putih (ppm)

\begin{tabular}{cccc}
\hline & Waktu Perendaman & \multicolumn{2}{c}{ Rata-rata Penurunan Kadar Formalin } \\
\cline { 3 - 4 } No & & Ppm & $\%$ \\
1. & 15 Menit & 5.714 & 33 \\
2. & 30 Menit & 5.261 & 31 \\
3. & 60 Menit & 6.122 & 36
\end{tabular}

Tabel 11 Pengaruh Interaksi Konsentrasi Larutan Air Garam dan Waktu Perendaman terhadap Penurunan Kadar Formalin Tahu Putih (ppm)

\begin{tabular}{|c|c|c|c|c|}
\hline \multirow[t]{2}{*}{ No } & \multirow[t]{2}{*}{ Perlakuan } & \multirow[t]{2}{*}{$\begin{array}{l}\text { Kadar formalin awal } \\
\text { rata-rata (ppm) }\end{array}$} & \multicolumn{2}{|c|}{$\begin{array}{c}\text { Rata-rata Penurunar } \\
\text { Kadar Formalin } \\
\end{array}$} \\
\hline & & & $\begin{array}{c}\mathrm{Ppm} \\
3193 \pm 40^{\mathrm{g}}\end{array}$ & \\
\hline 1. & Garam 5\%,15 Menit & 18.752 & $\begin{array}{l}3.193 \pm 40^{\mathrm{g}} \\
2.332 \pm 72^{\mathrm{i}}\end{array}$ & \\
\hline 2. & Garam 5\%, 30 Menit & 17.070 & $2.332 \pm 72^{1}$ & \\
\hline 3. & Garam 5\%, 60 Menit & 15.427 & $2.582 . \pm 14^{\mathrm{h}}$ & \\
\hline 4. & Garam $10 \%, 15$ Menit & 18.752 & $5.672 \pm 72^{e}$ & \\
\hline 5. & Garam $10 \%, 30$ Menit & 17.070 & $5.339 \pm 30^{f}$ & \\
\hline 6. & Garam $10 \%, 60$ Menit & 15.427 & $6.210 \pm 24^{d}$ & \\
\hline 7. & Garam $15 \%, 15$ Menit & 18.752 & $8.278 \pm 25^{b}$ & \\
\hline 8. & Garam $15 \%, 30$ Menit & 17.070 & $8.112 \pm 79^{c}$ & \\
\hline 9. & Garam $15 \%, 60$ Menit & 15.427 & $9.575 \pm 36^{a}$ & \\
\hline
\end{tabular}

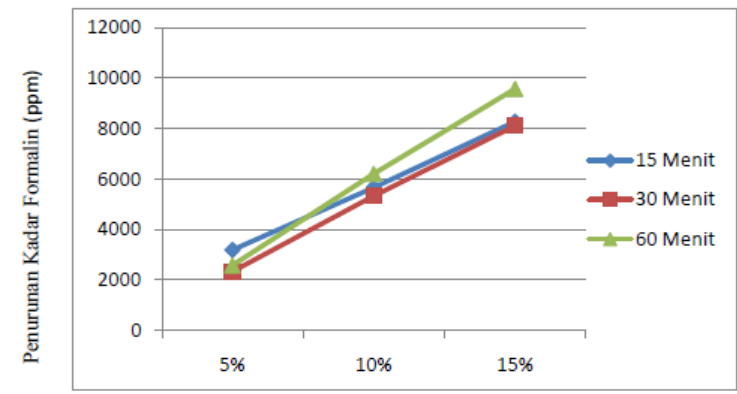

Kadar Larutan Air Garam

Gambar 2 Pengaruh Variasi Konsentrasi Larutan Air Garam dan Variasi Waktu Perendaman terhadap Kadar Formalin pada Tahu Putih 
Usaha tahu Ny. R merupakan home industry yang dikelola secara perorangan yang selama proses produksi maupun penjualan menggunakan peralatan yang terdiri dari : ember plastik, baskom besar, tungku perebusan, cetakan kayu, kain saring, nampan bambu, dan nampan plastik. Alat yang digunakan tersebut tidak memungkinkan terjadinya pencemaran formalin terhadap tahu yang diproduksi atau dijual. Alat yang memungkinkan untuk menimbulkan pencemaran formalin pada bahan makanan adalah peralatan yang terbuat dari melamin. Melamin merupakan persenyawaan (polimerisasi) kimia antara manometer formaldehid dan fenol. Bila kedua senyawa ini bergabung, sifat racun formaldehid akan hilang karena terlebur menjadi satu, yaitu melamin. Tetapi formaldehid dapat muncul dan bersifat racun bila melamin mengalami depolimerisasi karena paparan panas, sinar ultra violet, gesekan dan tergerusnya permukaan melamin hingga partikel formaldehid terlepas (Nisma et al. 2011, h.1)

Hasil pengukuran terhadap 36 toples sampel perlakuan dengan $\mathrm{pH}$ stick menunjukan warna yang sama. Setelah $\mathrm{pH}$ stick di bandingkan dengan $\mathrm{pH}$ indicator disimpulkan $\mathrm{pH}$ semua larutan adalah 7 (netral). $\mathrm{pH}$ netral ini diharapkan tidak mempengaruhi proses penurunan kadar formalin pada penelitian. $\mathrm{pH}$ larutan dapat mempengaruhi proses penyerapan formalin pada bahan makanan yang direndam. Penambahan air perasan belimbing wuluh dalam air yang digunakan untuk merebus udang putih dapat menurunkan atau menghilangkan kadar residu formalin udang putih. Hal ini disebabkan karena belimbing wuluh merupakan bahan makanan yang mempunyai kadar asam yang tinggi, yaitu $\mathrm{pH}=2$. Dalam beberapa proses kimia, sifat asam larutan dapat sebagai katalis, dan pemisahan aldehid dalam suatu campuran dapat dilakukan dengan asam (Wikanta et al, 2011, h.81).

Sampel untuk eksperimen ini adalah tahu putih yang sengaja direndam dalam formalin 2\%. Menurut Winarno (1994, h.104), perendaman tahu dalam formalin dosis agak tinggi (2\%) dalam waktu 30 menit dapat memperpanjang daya simpan tahu sampai 4-5 hari, tahu menjadi keras dan tidak berlendir.

Hasil pengujian di Laboratorium Kimia Organik, Fakultas MIPA, Unsoed Purwokerto, kadar formalin pada 36 sampel tahu putih yang telah direndam formalin 2\%, kemudian direndam dalam air, direndam dalam larutan air garam 5\%, 10\% dan 15\% selama 15 menit, 30 menit dan 60 menit dapat dilihat di tabel 3 dan tabel 4. Kadar formalin rata-rata sampel tahu putih tertinggi ada pada sampel dengan perlakuan perendaman air selama 15 menit sebesar 18.752 ppm. Kadar formalin sampel tahu putih terendah pada perlakuan perendaman air $15 \%$ selama 60 menit sebesar 5.853 ppm. Semua kadar formalin hasil pengukuran ini tidak layak dikonsumsi. Ambang batas formalin yang masih layak dikonsumsi adalah 20 ppm (Singgih, 2013, h. 69) .

Formalin merupakan bahan kimia yang sangat mudah diserap melalui saluran pernafasan. Bila formalin digunakan dalam jangka waktu lama akan mengakibatkan efek pada organ tubuh yaitu luka pada ginjal, paru-paru, kanker pada hidung dan dapat menyebabkan kematian. Pada konsentrasi $1 \mathrm{mg} / \mathrm{m} 3$ di udara dapat menyebabkan iritasi pada mata dan saluran pernafasan, dan pada konsentrasi yang lebih rendah dapat menyebabkan gangguan pernafasan. Konsentrasi 1-2\% kontak langsung dengan kulit dapat menyebabkan iritasi, konsentrasi 25\% bersifat korosif (Sanger dan Montalalu, 2008, h. 7).

Formalin sering digunakan sebagai desinfektan, dan bersifat toksik bagi kita karena apabila terisap bisa menyebabkan iritasi kepala serta keluar air mata, dan pusing. Apabila terminum, maka mulut, tenggorokan dan perut terasa terbakar, sakit menelan, mual, muntah, dan diare, kemungkinan terjadi pendarahan, sakit perut yang hebat, sakit kepala, hipotensi (tekanan darah rendah), kejang, tidak sadar hingga koma, bisa menyebabkan kematian (Purawisastra dan Sahara, 2014, h. 64).

Rata-rata penurunan kadar formalin tertinggi yang ditunjukan Tabel 5., yaitu pada perlakuan variasi konsentrasi larutan air garam dan variasi waktu perendaman terjadi pada sampel dengan perlakuan perendaman air garam $15 \%$ selama 60 menit, sebesar 9.575 ppm (62\%). Rata-rata penurunan kadar formalin terendah terjadi pada sampel tahu putih pada perlakuan perendaman dengan larutan air garam 5\% selama 30 menit, sebesar 2.332 ppm (14\%).

Hal ini sejalan dengan penelitian Sanger (2008, h.9), bahwa ikan cakalang berformalin yang direndam dalam air mengalami penurunan kadar formalin sebesar 78,33\%. Perendaman dalam air selama 60 menit dapat menurunkan kadar formalin pada ikan asin sebesar 61,25\%. Proses perendaman dalam air atau air garam dapat menurunkan kadar formalin karena sifat formalin yang mudah larut dalam air (Heri Warsito et al, 2015, h.149).

Hasil analisis anova factorial, signifikasi pengaruh perlakuan konsentrasi larutan air garam terhadap penurunan kadar formalin tahu putih, nilai $\mathrm{p}=0,000$ dan nilai $\mathrm{F}$ hitung=32.974,8. Nilai $\mathrm{p}<0,05$ dan nilai $F$ hitung $(32.974,8)>$ F table $(3,55)$, hal ini berarti Ho ditolak, yang berarti variasi konsentrasi larutan air garam berpengaruh terhadap penurunan kadar formalin pada tahu putih.

Pengaruh perlakuan konsentrasi kadar garam terhadap penurunan kadar formalin tahu putih (ppm) dapat dilihat pada Tabel 9. Perlakuan perendaman dengan konsentrasi kadar garam 15\% menunjukkan rata-rata penurunan kadar formalin tertinggi yaitu sebesar 8.655 ppm (51\%). Perendaman dengan konsentrasi larutan air garam $10 \%$ rata-rata menurunkan kadar formalin sebesar 5.741 ppm (34\%), dan penurunan rata-rata formalin terendah 
adalah 2.702 ppm (16\%) pada perendaman larutan air garam 5\%. Hal ini menunjukan bahwa perendaman dengan kadar garam 15\% merupakan dosis yang optimal untuk menurunkan kadar formalin pada penelitian ini.

Kadar garam mempunyai pengaruh terhadap penururnan kadar formalin. Semakin tinggi konsentrasi kadar garam maka semakin besar penurunan kadar formalin. Formalin dapat larut dalam air garam karena garam merupakan golongan surfaktan. Salah satu sifat surfaktan adalah dapat menimbulkan reaksi saponifikasi (proses pembentukan sabun). Larutan sabun (surfaktan) ini mempunyai daya bersih terhadap formalin yang lebih baik daripada larutan air saja (Harningsih dan Susilowati, 2015, h. 94).

Garam juga mempunyai sifat higroskopis, yang berarti mudah menyerap air. Kadar air tahu yang tinggi dapat terserap oleh larutan air garam. Terserapnya air dalam tahu ke air garam perendaman, menyebabkan formalin yang ada pada tahu ikut larut. Penurunan kadar formalin pada pangan juga dipengaruhi oleh perbedaan tekanan osmosa antara pangan dan larutan perendam sehingga terjadi perpindahan molekul air dari pangan ke larutan perendam. Melalui proses perpindahan molekul inilah maka maka formalin yang larut dalam pangan ikut keluar dan larut dalam larutan perendam (Grace dan Montalalu, 2009, h. 9)

Hasil analisis anova faktorial, signifikasi pengaruh perlakuan lama waktu perendaman terhadap penurunan kadar formalin tahu putih, nilai $\mathrm{p}=0,000$ dan nilai $\mathrm{F}$ hitung=691,1. Nilai $\mathrm{p}<0,05$ dan nilai $\mathrm{F}$ hitung $(691,1)>\mathrm{F}$ tabel $(2,93)$, hal ini berarti Ho ditolak, yang berarti variasi waktu perendaman berpengaruh terhadap penurunan kadar formalin pada tahu putih.

Pengaruh perlakuan variasi waktu perendaman terhadap penurunan kadar formalin tahu putih (ppm) dapat dilihat pada Tabel 10. Perlakuan perendaman selama 60 menit menunjukkan rata-rata penurunan kadar formalin tertinggi yaitu sebesar 6.122 ppm (36\%). Perendaman selama 15 menit rata-rata menurunkan kadar formalin sebesar 5.714 ppm (33\%), dan penurunan rata-rata formalin terendah adalah 5.261 ppm (31\%) pada perendaman selama 30 menit. Hal ini menunjukan bahwa perendaman selama 60 menit merupakan dosis optimal untuk menurunkan kadar formalin .

Lama waktu perendamanberpengaruh terhadap penurunan kadar formalin pada ikan asin bulu ayam (Maslukhah et al, 2014, h.161). Pada perendaman 5 menit penurunan formalin belum berarti secara statistik. Perendaman selama 15 menit dan 30 menit dapat menurunkan kadar formalin secara signifikan. Perendaman 30 menit memberikan hasil yang maksimal, yaitu kadar formalin turun 52\%. Hal ini disebabkan karena formalin mudah larut dalam air. Sehingga semakin lama waktu perendaman, maka formalin semakin larut, dan kadar formalin pada ikan asin semakin rendah. Penurunan kadar formalin tahu pada perendam air garam selama 30 menit (31\%) lebih rendah daripada penurunan kadar formalin pada ikan asin bulu ayam yang hanya direndam air selama 30 menit (52\%). Hal ini mungkin disebabkan karena pengaruh dari kadar garam awal bahan makanan tersebut. Tahu pada penelitian ini kadar garam awal $=0$, sedang ikan asin biasanya dibuat dengan kadar garam yang cukup tinggi (10-35\%)(Masyamir, 2001, h.10). Salah satu sifat garam adalah higroskopis, yang berarti mudah mengikat air (Subhan, 2014, h.292). Sifat higroskopis garam menyebabkan formalin yang ada pada ikan asin larut dalam air sehingga kadar formalin turun. Tingginya kadar garam ikan asin menyebabkan daya larut formalin pada ikan asin juga lebih tinggi. Larutnya garam juga menyebabkan air perendam mengandung garam. Sifat garam yang lain yaitu dapat menimbulkan reaksi saponifikasi (proses pembentukan sabun), sehingga daya bersih larutan yang mengandung garam terhadap formalin lebih baik.

Pada penelitian ini, penurunan kadar formalin tahu putih tidak sejalan dengan lamanya waktu perendaman, yaitu perendaman selama 15 menit lebih banyak menurunkan kadar formalin tahu putih dibandingkan perendaman selama 30 menit. Hal ini bisa terjadi karena penurunan kadar formalin selama proses perendaman juga dapat dipengaruhi oleh faktor tekstur dan kadar air bahan makanan. Penyerapan formalin pada paha ayam yang direndam formalin $1 \%$ lebih tinggi daripada daging dada ayam. Hal ini dimungkinkan karena protein pada paha ayam mempunyai struktur yang lebih mudah bereaksi dengan formalin dibandingkan struktur protein pada dada ayam. Penyerapan formalin pada 2 jenis tahu juga berbeda. Perbedaan penyerapan formalin pada tahu dapat terjadi karena tekstur dan kadar air yang berbeda. Tahu yang pada waktu perendaman lebih padat menyerap formalin lebih sedikit disbanding tahu yang berongga. (Purawisastra et al, 2011, h. 71).

Kadar air awal sampel tahu putih pada penelitian ini tidak diukur dan tidak biasa dikendalikan oleh peneliti. Menurut Sarwenda (2015, h.43) kadar air tahu dipengaruhi ketika proses pencetakan dan perendaman biji kedelai. Semakin lama waktu pencetakan semakin banyak air yang keluar sehingga kadar air tahu lebih rendah. Semakin lama perendaman biji kedelai maka struktur biji kedelai semakin lunak, hal ini menyebabkan air perendam semakin lebih mudah masuk ke dalam struktur sel kedelai sehingga kadar air tahu menjadi lebih tinggi. Ketika kandungan air dalam tahu tinggi, maka formalin akan lebih banyak terikat pada tahu disbanding pada tahu dengan kandungan air rendah.

Faktor lain yang ikut mempengaruhi penurunan kadar formalin pada makanan adalah jenis perlakuan yang diberikan pada bahan makanan. Variasi waktu perebusan dapat menurunkan kadarformalin pada 
bakso dan tahu. Makin lama proses perebusan maka prosentase penurunan kadar formalin pada bakso dan tahu makin tinggi. Perebusan pada bakso dan tahu selama (5,10, 15 dan 20) menit tanpa mengganti air rebusan dapat menurunkan kadar formalin dari bakso sebesar (26, 43, 51, dan 60)\% dan dari tahu (35, 45, 51 dan 66)\% (Purwanti, et al, 2014, h. 178). Proses perebusan dan perendaman air panas dapat menurunkan kadar formalin pada tahu. Perebusan tahu berformalin menurunkan kadar formalin lebih besar dibandingkan proses perendaman tahu dalam air panas. Penurunan kadar formalin pada tahu setelah direbus 10 menit adalah 64,77\%. Proses perendaman air panas selama 10 menit dapat menurunkan kadar formalin ada tahu 33,1\% (Muntaha et al., 2015, h. 90). Proses perebusan menyebabkan molekul formalin akan mudah lepas dari tahu dan menguap ke udara karena titik didih formalin sebesar 96o lebih rendah dari titik didih air.

\section{SIMPULAN}

1. Terdapat pengaruh konsentrasi larutan air garam terhadap penurunan kadar formalin, uji statistik nilai $\mathrm{p}=0,000(\mathrm{p}<0.05)$. Perendaman larutan air garam 15\% merupakan konsentrasi optimal menurunkan kadar formalin tahu putih, yaitu sebesar 8.655 ppm (51\%) .

2. Terdapat pengaruh waktu perendaman terhadap penurunan kadar formalin uji statistik nilai $\mathrm{p}=0,000 \quad(\mathrm{p}<0.05)$. Perendaman selamam 60 menit merupakan waktu optimal menurunkan kadar formalin pada tahu putih, yaitu sebesar $6.122 \mathrm{ppm}$ (36\%).

3. Terdapat pengaruh interaksi konsentrasi larutan air garam dan waktu perendaman terhadap penurunan kadar formalin, uji statistik nilai $\mathrm{p}=0,000(\mathrm{p}<0.05)$. Perendaman larutan air garam $15 \%$ selama 60 menit merupakan kombinasi konsentrasi dan waktu perendaman optimal menurunkan kadar formalin tahu putih, yaitu sebesar 9.575 ppm (62\%).

\section{DAFTAR PUSTAKA}

Afrianti, L.H., 2014, Teknologi Pengawetan Pangan, cetakan ketiga, edisi revisi, Bandung (ID) : Alfabeta

BPOM, 2009, Penetapan Batas Maksimum Cemaran Mikroba dan Kimia

Effendi, S., 2012, Teknologi Pengolahan dan Pengawetan Pangan, Bandung (ID) : Alfabeta

Faradila, Y. Alioes, Elmatris. 2014. Identifikasi Formalin pada Bakso yang Dijual pada Beberapa Tempat di Kota Padang. Jurnal Kesehatan Andalas, 3(2) : 156-158.
Harningsih, T. dan I.T. Susilowati, Metode Reduksi Tahu Berformalin Menggunakan Variasi Konsentrasi Air Garam Yang Ditambahkan Dengan Ekstrak Bawang Putih (Allium sativum L.), Jurnal KesMaDaSka, (89 - 95)

Hastuti, S., 2010. Analisis Kualitatif Dan Kuantitatif Formaldehid. Pada Ikan Asin Di Madura. Agrointek. 4 (2): 132- 137

Maslukhah, P. Suhariyadi, W. S. Wulan. 2014. Perendaman Ikan Asin Bulu Ayam (Thryssa setirostris) dalam Larutan $\mathrm{NaCl} 5 \%$ Sebagai Upaya Penurunan Kadar Formalin. Jurnal Analis Kesehatan Sains, 3 (1): 158-161.

Muntaha, A., Haitami, N. Hayati, 2015, Perbandingan Penurunan Kadar Formalin Pada Tahu Yang Direbus Dan Direndam Air Panas, Medical Laboratory Technology Journal, 1 (2) : 84-90

Notoatmodjo, S., 2010, Metodologi Penelitian Kesehatan, Jakarta (ID) : Rineka Cipta. Purawisastra, S. Dan E. Sahara. 2011. Penyerapan Formalin oleh Beberapa Jenis Bahan Makanan Serta Penghilangannya Melalui Perendaman dalam Air Panas (The Adsorption of Formaldehyde By Some Foodstuffs And Its Elimination By Soaking Them In Hot Water). Pgm, 34(1):63-74.

Purwanti, A., S. Rismini, B. Mujianto, 2014, Kandungan Formalin Pada Bakso dan Tahu Setelah Dilakkan Beberapa, Variasi Perebusan, Jurnal Ilmu dan Teknologi Kesehatan, 1(2) : 169-179

Sanger, G. dan L. Montololu.2008. Metode Pengurangan Kadar Formalin Pada Ikan Cakatang. Warta WIPTEK (32) 6-10

Santjaka, A., 2011, Statistik untuk Penelitian Kesehatan, Yogyakarta (ID) : Nuha Medika

Singgih, H., 2013, Uji Kandungan Formalin Pada Ikan asin Menggunakan Sensor Warna dengan Bantuan FMR (Formalin Main Reagent). Jurnal Eektronika dan Teknologi (Eltek), 11 (1): 55-70.

Subhan, 2014, Analisis Kandungan Iodium Dalam Garam Butiran Konsumsi Yang Beredar Di Pasaran Kota Ambon, Jurnal Fikratuna 6 (2) : $290-303$

Tri Cahyono, 2014, Pedoman Penulisan Proposal Penelitian dan Karya Tulis Ilmiah, Purwokerto: Kementerian Kesehatan RI 
Politeknik Kesehatan Depkes Semarang Jurusan Kesehatan Lingkungan

Wikanta, W., Y. Abdurrajak, Sumarno, dan M. Amin, 2011, Pengaruh Penambahan Belimbing Wuluh (Averrhoa blimbi L.) dan Perebusan Terhadap Kadar Residu Formalin Dan Profil Protein Udang Putih (Letapenaeus vannamei) Berformalin Serta Pemanfaatannya Sebagai sumber Pendidikan Gizi dan Keamanan Pangan
Pada Masyarakat, Seminar Nasional VIII Pendidikan Biologi, 76 - 84

Winarno, F.G., 1993, Pangan, Gizi, Teknologi dan Konsumen, Jakarta (ID) : Gramedia Pustaka Utama

Winarno, F.G. dan T.S. Rahayu, 1994, Bahan Tambahan Untuk Makanan dan Kontaminan, Jakarta (ID) : Pustaka Sinar Harapan 